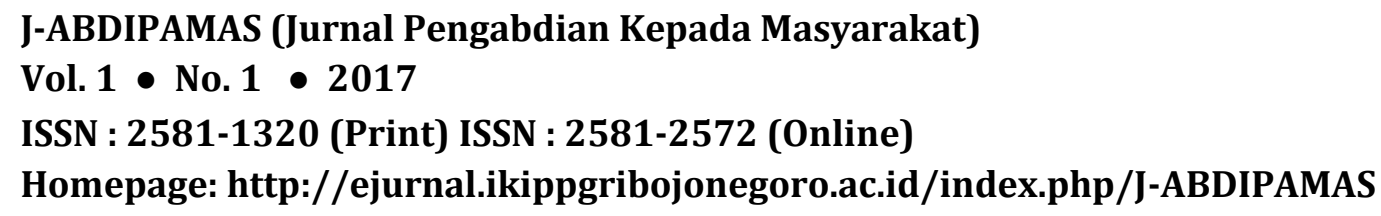

ISSN : 2581-1320 (Print) ISSN : 2581-2572 (Online)

Homepage: http://ejurnal.ikippgribojonegoro.ac.id/index.php/J-ABDIPAMAS

\title{
PEMBERDAYAAN BUDAYA LITERASI MENULIS PUISI PADA PESERTA DIDIK SMK NEGERI 1 KANOR BOJONEGORO
}

\author{
Cyntia Heru Woro Prastiwi ${ }^{1}$, Meiga Ratih Tirtanawati ${ }^{2}$, Yuniarta Ita Purnama ${ }^{3}$, \\ Oktha Ika Rahmawati ${ }^{4}$ \\ ${ }^{1}$ IKIP PGRI Bojonegoro. Email: chwphi@gmail.com \\ ${ }^{2}$ IKIP PGRI Bojonegoro. Email: meigaratihtirtanawati@gmail.com \\ ${ }^{3}$ IKIP PGRI Bojonegoro. Email: niar.purnama@gmail.com \\ ${ }^{4}$ IKIP PGRI Bojonegoro. Email: geodesy2001@gmail.com
}

\begin{abstract}
This article is resulted from the activity of Community Service Program located at State Vocational High School 1, Kanor, Bojonegoro. The low student's ability in English and the lack of achievement in poem indicated the need of empowerment in writing poem at this school. This article aimed at describing the empowerment process of literary culture of writing poem in Indonesian and English to the graders XI and XII. Indonesia poem took the themes of TKR (Teknik Kendaraan Ringan or Simple Vehicle Technique), Multimedia, Pemasaran (Marketing), and TPHP (Teknik Pengolahan Hasil Pertanian or Agricultural Products Processing Technique). Meanwhile, English poem took free theme but was limited to the six types of poems namely acrostic, cinquain, haiku, tanka, diamante, and calligram. Indonesian poem on expertise program of Vocational High School was intended for deepening students' understanding on their study fields, while English poem was aimed at improving students' abilities in English. The results of this Community Service Program reported that there were 34 out of 94 students' poems fulfilling the criteria of good poem and deserved to be published. Although the poem feasibility only reached $36.2 \%$, this percentage could be categorized as quite good first achievement for the students.
\end{abstract}

Keywords: Vocational High School, Poetry literacy, English, Indonesian.

\begin{abstract}
ABSTRAK
Artikel ini merupakan hasil dari kegiatan Pengabdian kepada Masyarakat (PKM) yang bertempat di SMK Negeri 1 Kanor, Bojonegoro. Rendahnya kemampuan Bahasa Inggris serta belum adanya prestasi dibidang seni puisi pada peserta didik SMK Negeri I Kanor, Bojonegoro mengindikasikan perlunya pemberdayaan menulis puisi pada sekolah ini. Artikel ini bertujuan menggambarkan bagaimana memberdayakan budaya literasi menulis puisi berbahasa Indonesia dan berbahasa Inggris pada peserta didik kelas XI and XII. Puisi berbahasa Indonesia mengambil 4 tema yaitu TKR (Teknik Kendaraan Ringan), Multimedia, Pemasaran, dan TPHP (Teknik Pengolahan Hasil Pertanian), sedangkan puisi berbahasa Inggris mengambil tema bebas tapi bentuk puisi terbatas pada 6 jenis yaitu acrostic, cinquain, haiku, tanka, diamante, dan calligram. Puisi berbahasa Indonesia bertema program keahlian SMK bertujuan untuk memperdalam pemahaman mereka tentang materi jurusan masing-masing, sedangkan puisi berbahasa Inggris bertujuan meningkatkan kemampuan Bahasa Inggris peserta didik sekaligus memperkenalkan bentuk-bentuk puisi berbahasa Inggris. Hasil kegiatan PKM ini menunjukkan bahwa terdapat 34 puisi dari total 94 puisi peserta didik yang terpilih dan memenuhi kriteria bagus dan layak terbit. Meskipun kelayakan puisi hanya mencapai 36,2\%, persentase ini merupakan pencapaian pertama peserta didik yang cukup bagus.
\end{abstract}

Kata kunci: SMK, Literasi puisi, Bahasa Inggris, Bahasa Indonesia. 


\section{PENDAHULUAN}

Sekolah Menengah Kejuruan (SMK) adalah jenjang pendidikan menengah yang mengutamakan pengembangan kemampuan peserta didik untuk melaksanakan jenis pekerjaan tertentu. Pendidikan menengah kejuruan mengutamakan penyiapan peserta didik untuk memasuki lapangan kerja serta mengembangkan sikap profesional. Sesuai dengan bentuknya, SMK menyelenggarakan program-program pendidikan keahlian yang disesuaikan dengan jenis-jenis lapangan kerja sehingga lulusan SMK dicetak siap bekerja pada bidang tertentu.

SMK Negeri 1 Kanor, Bojonegoro merupakan satu-satunya SMK yang ada di Kecamatan Kanor, Kabupaten Bojonegoro yang didirikan pada tahun 2008. Dengan potensi yang dimilikinya, SMK Negeri 1 Kanor membuka 4 (empat) kompetensi keahlian yaitu: Teknik Kendaraan Ringan (TKR), Teknik Pengolahan Hasil Pertanian (TPHP), Pemasaran, dan Multimedia. SMK Negeri 1 Kanor memiliki visi mewujudkan lembaga diklat berstandar nasional untuk menyiapkan tenaga terampil yang profesional, berwawasan IPTEK dan IMTAQ yang kompetitif. Sedangkan misi SMK Negeri 1 Kanor adalah mewujudkan KBM yang berkualitas, mewujudkan pendidikan berbasis kompetensi kecakapan hidup dan kewirausahaan didasari pengembangan diri yang berkelanjutan, mewujudkan sekolah berwawasan lingkungan, mengembangkan unit produksi, mengembangkan karakter peserta didik yang berakar pada nilai-nilai budaya Bangsa Indonesia, serta membentuk pribadi yang beriman dan bertakwa.

Kualitas lulusan SMK, salah satunya dapat diukur dari hasil capaian dalam Ujian Nasional yang dilaksanakan setiap tahun. Nilai Ujian Nasional SMK Negeri 1 Kanor pada tahun 2017 memiliki rincian sebagai berikut: mata pelajaran Bahasa Inggris 70,00, KMP 88,20, Matematika 92,50, dan Bahasa Indonesia 94,00. Capaian tersebut menunjukkan bahwa mata pelajaran Bahasa Inggris menduduki posisi nilai terendah dibandingkan dengan mata pelajaran lain. Padahal kemampuan berbahasa khususnya Bahasa Inggris merupakan salah satu life skill yang dibutuhkan dalam dunia kerja. Permasalahan lain yang dihadapi SMK Negeri 1 Kanor adalah belum memiliki prestasi dalam bidang seni, salah satunya adalah seni cipta-baca puisi. Faktor budaya masyarakat setempat yang kurang mendukung dan kualitas SDM peserta didik itu sendiri terutama terkait dengan kemampuan Bahasa Inggris dan seni merupakan penyebab permasalahan pada SMK Negeri 1 Kanor. Dengan pemberdayaan menulis literasi puisi berbahasa Indonesia dengan tema puisi program keahlian SMK diharapkan mampu membangkitkan dan meningkatkan kreativitas seni para peserta didik karena kata-kata dalam puisi mereka nantinya harus dikaitkan dengan bidang ilmu sesuai jurusanSMK masing-masing.

Berdasarkan analisis situasi tersebut, Pengabdian Kepada Masyarakat (PKM) ini bertujuan memberdayakan budaya literasi menulis puisi berbahasa Indonesia dan berbahasa Inggris bagi peserta didik SMK Negeri 1 Kanor, dengan bernitra Kepala Sekolah, guru Bahasa Indonesia serta Bahasa Inggris. Dalam hal ini, Bahasa Inggris akan dijadikan sarana penulisan puisi dengan tema bebas, dengan tujuan mengenalkan jenisjenis puisi berbahasa Inggris sekaligus menumbuhkan semangat belajar Bahasa Inggris, sedangkan Bahasa Indonesia akan digunakan untuk penulisan puisi dengan tema sesuai dengan jurusan masing-masing dengan tujuan menggali minat seni puisi sekaligus 
memperdalam pemahaman akan bidang keahlian mereka. Puisi dipilih sebagai media untuk memberdayakan literasi menulis karena puisi bisa digunakan untuk mengekpresikan ide/pikiran para peserta didik sekaligus menggali dan mengasah skill berbahasa. Puisi dijadikan sasaran kegiatan PKM ini karena puisi dapat digunakan untuk meningkatkan skill peserta didik dibidang seni yang selama ini belum terfasilitasi. Dengan kata lain, PKM ini bertujuan meningktakan mutu layanan SMK Negeri 1 Kanor untuk pengembangan budaya literasi menulis, pengembangan karya seni, dan pengajaran Bahasa Inggris.

Pengenalan puisi berbahasa Inggris dan puisi berbahasa Indonesia serta pembiasaan untuk menulis puisi merupakan bagian dari program pemerintah yang disebut dengan GLS (Gerakan Literasi Sekolah). Menurut Permendikbud No. 23 Tahun 2015, Gerakan Literasi Sekolah merupakan salah satu kegiatan yang dapat menumbuhkan budaya menulis peserta didik sehingga dapat meningkatkan keterampilan menulis peserta didik. Dalam gerakan ini peserta didik dapat dikenalkan dan dibiasakan untuk menulis puisi berbahasa Indonesia dan bahasa Inggris. Siswa SMA/SMK di Indonesia menjadi target utama GLS karena mereka berkemungkinan memiliki potensi dan kemampuan yang luar biasa untuk bersaing dengan siswa dari sekolah lain bahkan dari negara lain. Beberapa parameter sekolah dalam membangun budaya literasi dapat dilihat dari lingkungan fisik (pemajangan hasil karya peserta didik), lingkungan social dan afektif (penghargaan terhadap hasil karya peserta didik), serta lingkungan akademis (kesempatan pengembangan professional potensi literasi peserta didik).

Salah satu cara untuk memberdayakan budaya literasi menulis di sekolah adalah melalui puisi. Puisi, bersama-sama dengan prosa dan drama seharusnya diajarkan sebagai bagian dari teks literasi (Anderson \& Anderson, 1998). Puisi memiliki kemiripan dengan jenis teks bacaan (genre) yang sering disajikan sebagai sebuah materi pelajaran bahasa. Puisi dapat berfungsi untuk menyampaikan sebuah cerita (teks narrative), membujuk orang (teks argumentative), dan bahkan menggambarkan orang, benda, atau alam (teks descriptive). Sebuah puisi dapat berfungsi sebagai pengenalan singkat tentang literasi sebelum mengenal bentuk-bentuk literasi lain yang lebih panjang seperti cerpen, novel, dan drama. (Hadaway, et al., 2001).Pada akhirnya, puisi bisa memberi banyak kesempatan kepada peserta didik untuk belajar komponen maupun ketrampilan bahasa (Smart, 2010).Terkadang puisi memiliki bahasa yang puitis seperti metafora dan menggunakan diksi khusus yang berisi konotasi, allusio, ambiguitas, bahkan ironi. Akan tetapi, tidak semua puisi harus memiliki irama yang bisa membatasi pikiran dan pilihan kata para peserta didik. Puisi yang simple yang berisi kata-kata yang mudah dan umum, memiliki keunikan pola, serta tidak harus memiliki irama, bisa diajarkan kepada siswa sekolah, sebagai contoh jenis puisi acrostic, cinquain, haiku, tanka, diamante, dan puisi bentuk/kaligram.

Dengan pembiasaan menulis puisi ini, diharapkan dapat meningkatkan kemampuan berbahasa khususnya Bahasa Inggris, sehingga diharapkan dapat meningkatkan nilai UN untuk mata pelajaran Bahasa Inggris. Selain itu, potensi jiwa seni peserta didik khususnya dalam hal cipta-baca puisi juga diharapkan mengalami 
peningkatan, sehingga hasil akhir yang diharapkan adalah peserta didik SMK Negeri 1 Kanor dapat menjuarai lomba cipta-baca puisi antar SMK se-Bojonegoro. Manfaat lain Gerakan Literasi Sekolah, khususnya literasi menulis puisi ini adalah sekolah dapat menghasilkan karya-karya puisi peserta didik yang dapat dikumpulkan dalam satu buku kumpulan puisi atau menampilkan puisi-puisi tersebut dalam majalah dinding sekolah. Selain itu, puisi-puisi tersebut juga dapat dikirmkan pada rubrik puisi dimedia massa seperti koran, majalah, ataupun media online lainnya. Dengan demikian, peserta didik dapat merasakan manfaat yang lebih besar lagi dengan adanya GLS di sekolah ini.

Melalui kegiatan PKM ini, budaya literasi menulis khususnya menulis puisi diharapkan terbentuk dikalangan peserta didik karena mereka sudah mengetahui jenisjenis puisi dan teknik penulisan puisi sehingga dapat menyalurkan ide dan perasaan melalui puisi. Mereka juga akan termotivasi untuk meningkatkan kemampuan berbahasa Indonesia dan Bahasa Inggris melalui penulisan puisi.

\section{METODE PELAKSANAAN}

Kegiatan PKM ini diadakan di SMK Negeri 1 Kanor, Desa Sumberwangi, Kecamatan Kanor, Kabupaten Bojonegoro. Ada 4 kelas yang dijadikan sasaran kegiatan ini yaitu kelas XI jurusan TKR (Teknik Kendaraan Ringan) dan Multimedia, serta kelas XII jurusan Pemasaran dan TPHP (Teknik Pengolahan Hasil Pertanian). Kegiatan ini dilaksanakan hanya satu hari yaitu pada tanggal 14 September 2017.

Tahapan-tahapan yang akan dilakukan untuk memberdayakan budaya literasi menulis puisi pada SMK Negeri 1 Kanor adalah sebagai berikut:

1. Memberikan dan menjelaskan materi tentang jenis-jenis puisi simple/sederhana di 4 kelas yaitu kelas XI jurusan Teknik Kendaraan Ringan dan Multimedia serta kelas XII jurusan Teknologi Pengolahan Hasil Pertanian dan Pemasaran. Jenis puisi Bahasa Inggris yang dijelaskan meliputi akrostik, cinquain, haiku, tanka, diamante, dan kaligram.

2. Menunjukkan contoh-contoh enam jenis puisi simple berbahasa Inggris dan 4 contoh puisi berbahasa Indonesia terkait bidang keahlian TKR, TPHP, Multimedia, dan Pemasaran.

3. Menjelaskan aspek-aspek kebahasaan tiap jenis puisi.

4. Memotivasi siswa untuk menciptakan puisi terbaik mereka dengan cara menampilkannya dalam media online/offline dan bahkan mengkompilasinya menjadi sebuah buku untuk naskah-naskah puisi yang terpilih. Pihak sekolah juga disarankan untuk memajang hasil karya puisi peserta didik dalam majalah dinding sekolah.

5. Memberi instruksi kepada tiap peserta didik untuk menulis sebuah puisi berbahasa Indonesia dengan tema sesuai dengan jurusan kelas masing-masing dan sebuah puisi berbahasa Inggris dengan tema bebas sesuai dengan jenis-jenis puisi yang sudah dijelaskan.

6. Melakukan pendampingan pembuatan puisi bersama-sama dengan guru Bahasa Indonesia dan guru Bahasa Inggris sekolah.

7. Mengumpulkan dan menyeleksi puisi para peserta didik. 
8. Mengkompilasi puisi-puisi terpilih.

9. Memberikan penghargaan kepada para peserta didik yang puisinya terpilih untuk diterbitkan.

10. Membantu teknis penerbitan kompilasi puisi-puisi tersebut menjadi sebuah buku atau mengirimkannya ke media online/offline.

\section{HASIL DAN PEMBAHASAN}

Kegiatan Pemberdayaan Siswa Kelas XI jurusan TKR dan multimedia dan Kelas XII jurusan TPHP dan pemasaran/niaga dalam menumbuhkan budaya literasi menulis puisi sederhana Bahasa Inggris dan Bahasa Indonesia telah dilaksanakan dengan baik. Dengan menggunakan kamus online/offline serta kamus cetak dengan dibimbing tim PKM, total puisi yang dihasilkan peserta didik ada 94 puisi dengan rincian sebagai berikut: 26 puisi dari jurusan TKR, 24 puisi dari jurusan multimedia, 20 puisi dari jurusan TPHP, dan 24 puisi dari jurusan Pemasaran/Niaga. Setelah direview berdasarkan kesesuaian topik, kelayakan bahasa, serta jenis puisi, ada beberapa puisi yang terpilih untuk dibukukan yaitu 11 puisi dari jurusan TKR, 7 puisi dari jurusan multimedia, 7 puisi dari jurusan TPHP, dan 9 puisi dari jurusan Pemasaran/Niaga. Total keseluruhan puisi yang dibukukan ada 34 puisi. Hasil rincian puisi terkumpul dan puisi terseleksi dapat dilihat di Tabel 1. Meskipun hanya 36,2\% (34 puisi dari total 94 puisi) yang dinyatakan layak untuk dibukukan, persentase ini merupakan pencapaian pertama yang cukup bagus.

Tabel 1. Rincian Puisi Terkumpul dan Puisi Terseleksi

\begin{tabular}{llcc}
\hline No & \multicolumn{1}{c}{ Program Keahlian } & Puisi Terkumpul & Puisi Terseleksi \\
\hline 1. & Kelas XI TKR & 26 & 11 \\
\hline 2. & Kelas XI Multimedia & 24 & 7 \\
\hline 3. & Kelas XII TPHP & 20 & 7 \\
\hline 4. & Kelas XII Pemasaran/Niaga & 24 & 9 \\
\hline & Total & 94 & 34 \\
\hline
\end{tabular}

Tim memulai pembelajaran dengan cara mempresentasikan dan menjelaskan macam-macam puisi sederhana Bahasa Inggris dan memberikan contoh puisi berbahasa Indonesia yang sesuai dengan jurusan mereka. Siswa terlihat sangat antusias dan memperhatikan penjelasan Tim. Bagi mereka ini adalah pertama kalinya belajar puisi Bahasa Inggris dan puisi Bahasa Indonesia dengan menggunakan istilah-istilah keilmuan mereka. Setelah itu tim menyuruh siswa untuk membuat puisi berdasarkan pilihan mereka masing-masing. Sebagian ada yang membuat puisi Bahasa Inggris berbentuk acrostic, cinquain, haiku, tanka, diamante dan calligram. Sebagian yang lain membuat puisi Bahasa Indonesia dengan menggunakan istilah-istilah yang sesuai dengan jurusan mereka masing-masing.

Pembelajaran berlangsung didalam kelas dan diluar kelas. Hal ini dilakukan untuk menghadirkan suasana dan pengalaman belajar yang berbeda, menyenangkan, santai, nyaman dan menarik, serta untuk membantu siswa dalam mencari ide puisi. Sebelum pembelajaran, tim meminta mereka untuk membawa kamus 
online/offline/cetak guna membantu mereka dalam pembuatan puisi Bahasa Inggris. Meskipun awalnya mereka kesulitan namun karena antusias dan semangat mereka, pada akhirnya terciptalah puisi-puisi yang bagus.

Dengan adanya kegiatan "Pemberdayaan Budaya Literasi Menulis Puisi" ini, peserta didik mendapat pengetahuan tentang jenis-jenis puisi sederhana Bahasa Inggris dengan tema bebas dan puisi Bahasa Indonesia dengan tema atau istilah-istilah sesuai bidang keahlian mereka di SMK. Puisi bertema bidang keahlian ini bertujuan agar peserta didik mampu mengekspresikan pemahaman mereka tentang keilmuannya, sedangkan puisi bebas berbahasa Inggris bertujuan untuk meningkatkan kemampuan Bahasa Inggris mereka. Selain itu, melalui kegiatan ini para peserta didik juga bisa meningkatkan kreatifitas seni dibidang puisi. Sebagian besar peserta didik membuat puisi bertemakan cinta karena usia mereka yang tergolong remaja sangat erat kaitannya dengan cinta. Disinilah perlunya penggalian dan peningkatan kreatifitas peserta didik supaya mereka bisa menyalurkan ide melalui puisi dengan topik/tema yang lebih bervariasi.

Contoh puisi berbahasa Indonesia tentang tema program-program keahlian yang ada di SMK Negeri 1 Kanor, Bojonegoro dapat dilihat pada Tabel 2 dan 3.

Tabel 2. Puisi Program Keahlian TKR dan Multimedia

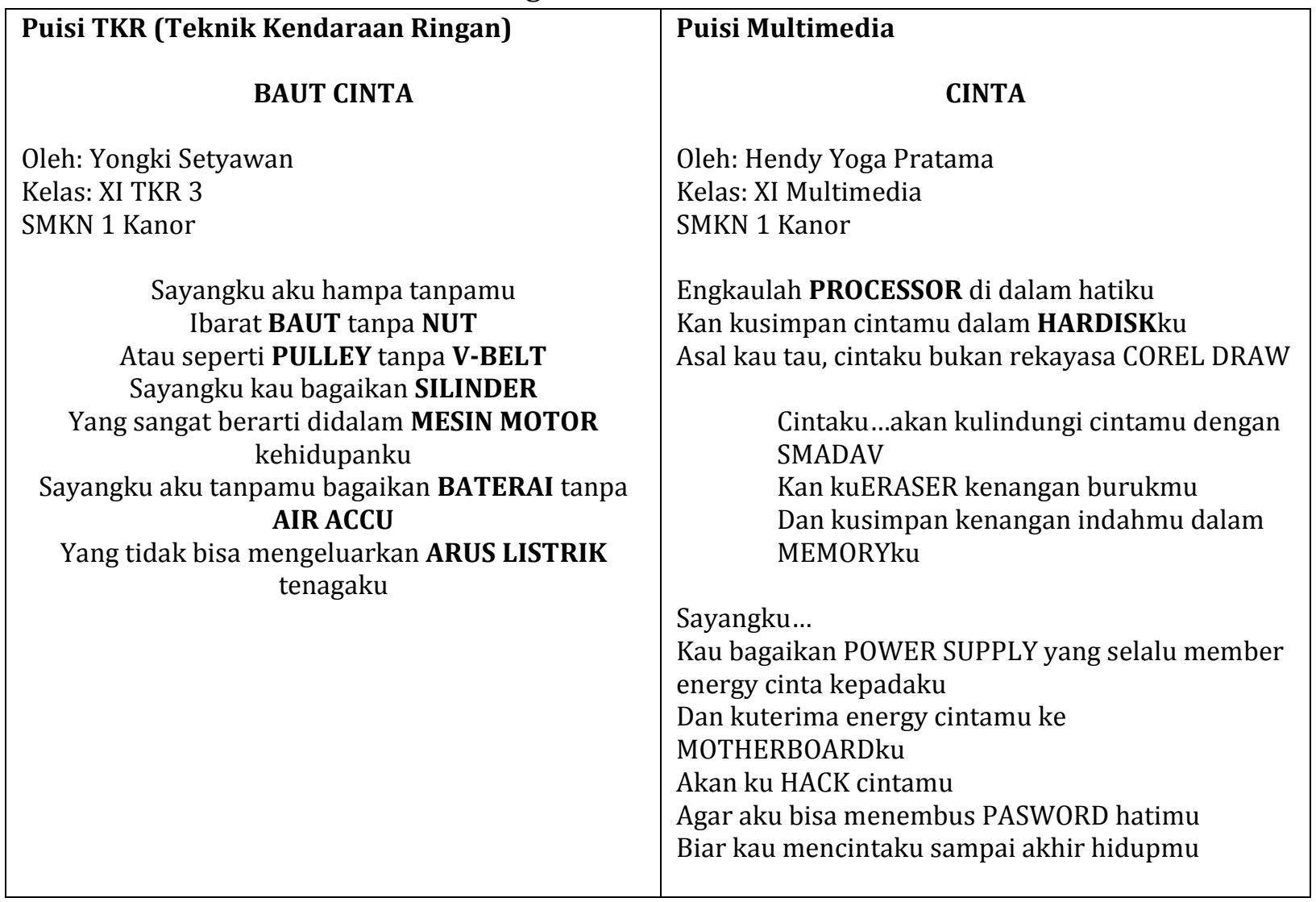


Tabel 3. Puisi Program Keahlian TPHP dan Pemasaran/Niaga

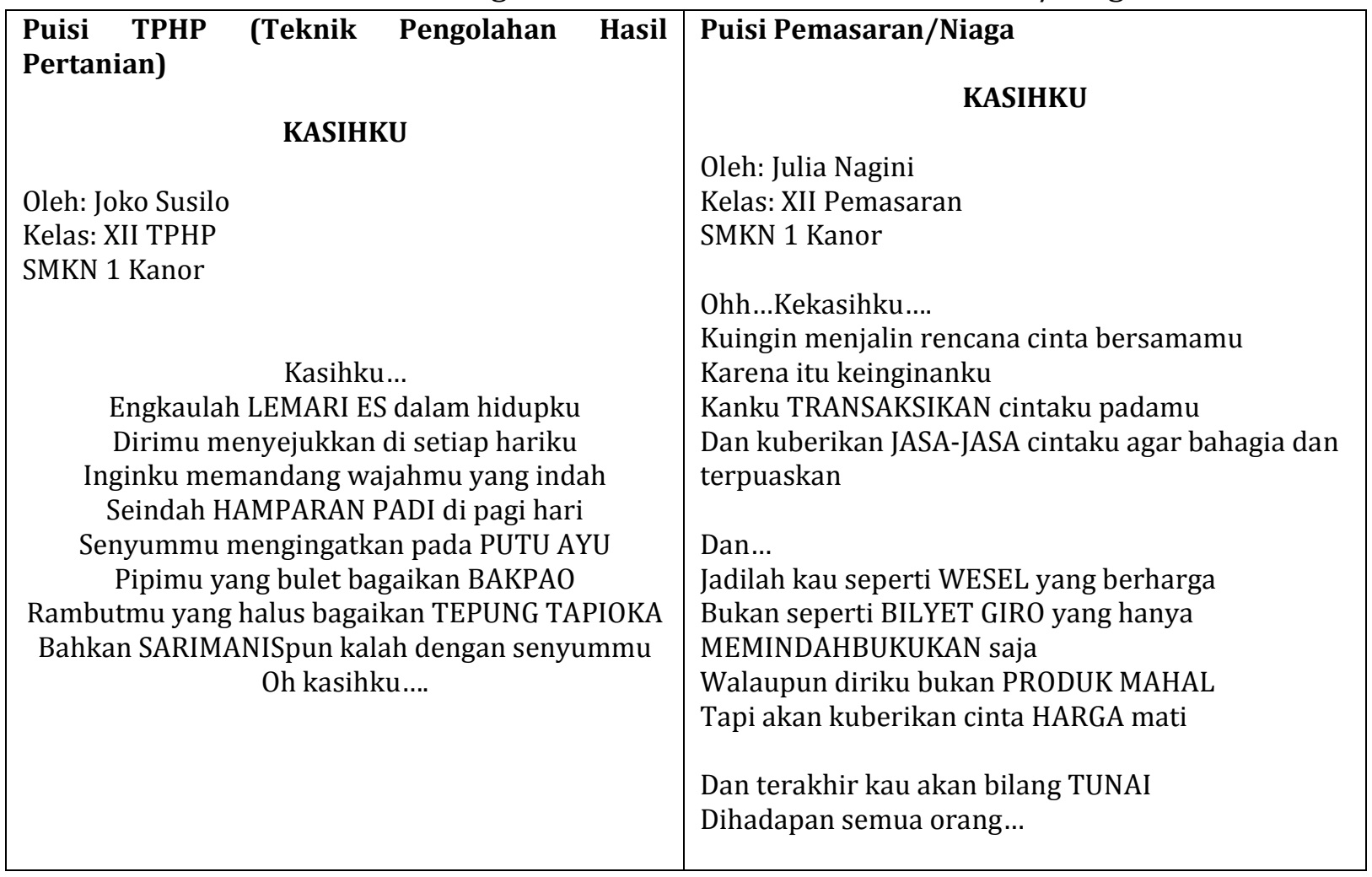

Contoh puisi berbahasa Inggris (jenis Cinquain, Acrostic, dan Calligram) karya peserta didik SMK Negeri 1 Kanor, Bojonegoro dapat dilihat pada Tabel 4 dan 5 serta Gambar 1 dan 2.

Tabel 4. Puisi Jenis Cinquain

\begin{tabular}{|l|ll|}
\hline Cinquain & Cinquain \\
Rainbow & Indonesia \\
Fancy amazing & Beloved Country \\
Decorating, beautifying, illuminating & Thousands island outstretched \\
$\begin{array}{l}\text { You emerge after rain } \\
\text { Heaven }\end{array}$ & Beautiful and amazing place & \\
& Home & \\
& & Oleh: Eri Silfi Intan H \\
Oleh : Afifatul Lailiah & & Kelas: XII Pemasaran 1 \\
Kelas: XII Pemasaran 1 & & SMKN 1 Kanor \\
\hline
\end{tabular}

Tabel 5. Puisi Jenis Acrostic

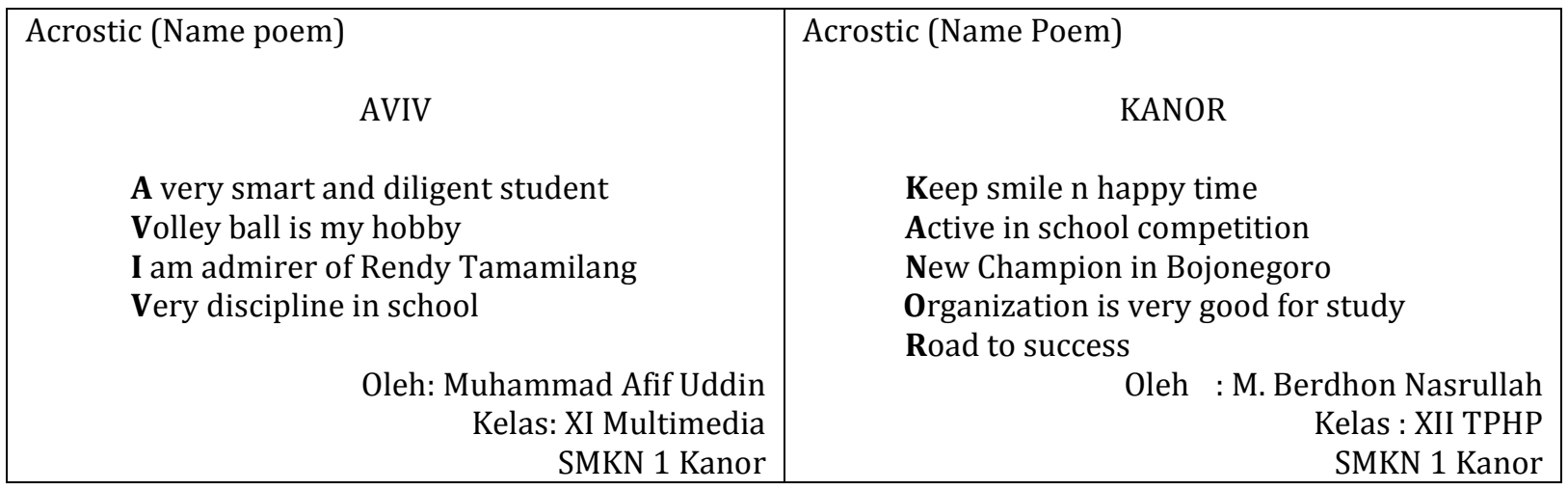




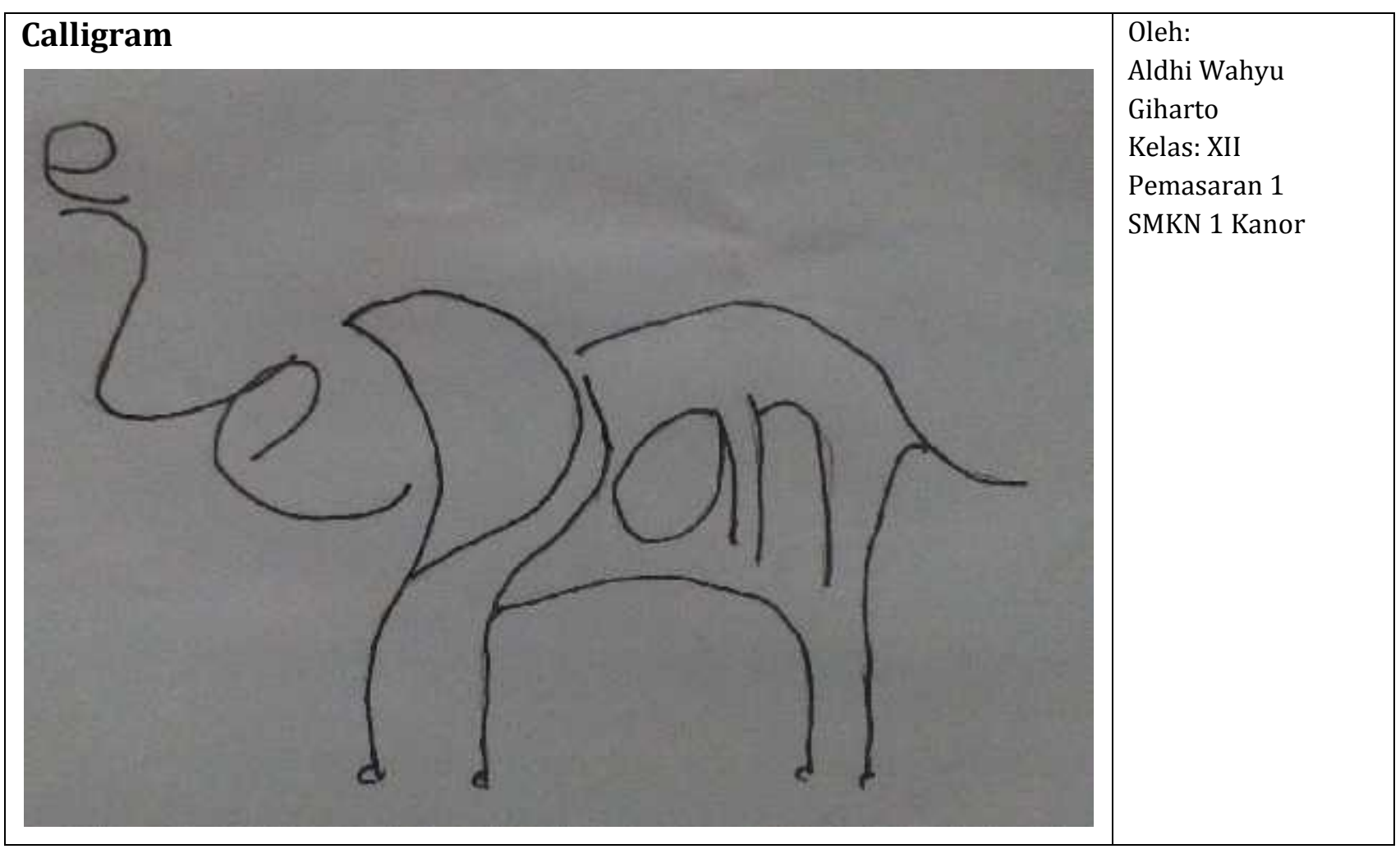

Gambar 1. Calligram “Single Word” tentang Gajah

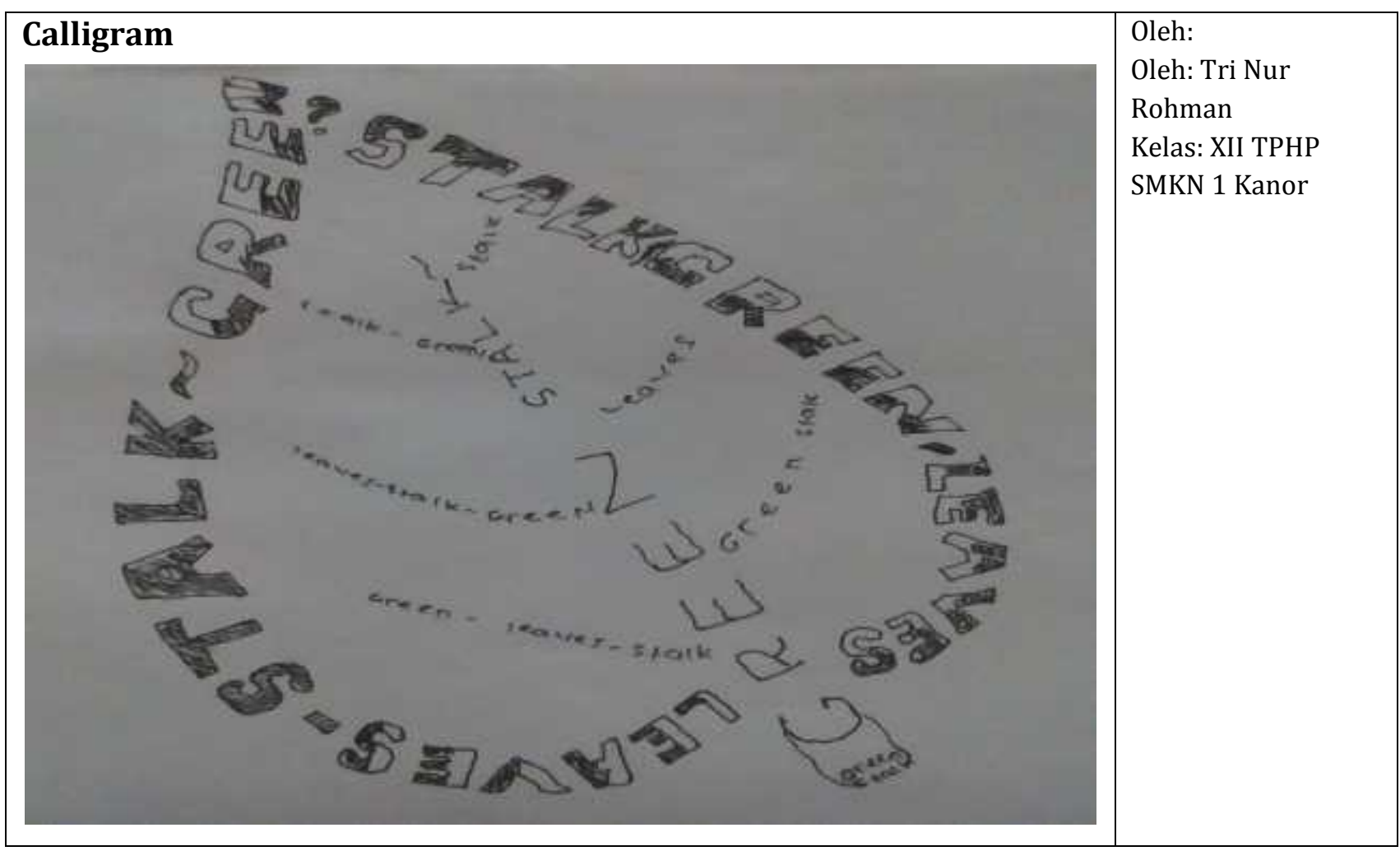

Gambar 2. Calligram "Multi Words” tentang Daun 


\section{SIMPULAN}

Pemberdayaan budaya literasi menulis puisi merupakan salah satu wujud dari Gerakan Literasi Sekolah (GLS). Pengenalan puisi sederhana berbahasa Indonesia dan berbahasa Inggris diharapkan mampu meningkatkan kemampuan dan minat berbahasa, terutama Bahasa Inggris serta mampu menumbuhkan jiwa seni puisi para peserta didik. Puisi berbahasa Indonesia mengambil tema sesuai dengan 4 program keahlian yang ada di SMK Negeri 1 Kanor, Bojonegoro yaitu TKR (Teknik Kendaraan Ringan), Multimedia, TPHP (Teknik Pengolahan Hasil Pertanian), dan Pemasaran/Niaga. Puisi berbahasa Inggris mengambil tema bebas tapi hanya terbatas pada 6 jenis puisi yaitu Acrostic, Cinquain, Haiku, Tanka, Diamante, dan Calligram. Terdapat 34 puisi dari total 94 puisi atau hanya sekitar $36.2 \%$ puisi peserta didik yang memenuhi kriteria layak berdasarkan kesesuaian topik, bahasa, dan jenis puisi. Bagi peserta didik, kegiatan ini merupakan pertama kalinya mereka mengenal, memahami, dan membuat puisi Bahasa Indonesia tentang keahlian ilmu serta 6 jenis puisi Bahasa Inggris. Dengan demikian, persentase ini bisa dikategorikan cukup bagus untuk pencapaian hasil peserta didik yang pertama kalinya.

\section{DAFTAR RUJUKAN}

Anderson, M., \& Anderson, H. (1998). Text Types in English 3. London: Macmillan.

Hadaway, N.L., Vardell, S.M., \& Young, T.A. (2001). Scaffolding Oral Language Development through Poetry for Students Learning English. The Reading Teacher, 45 (8).

Permendikbud No. 23 Tahun 2015. Budi Pekerti. Diakses tanggal 28 Agustus 2017 dari http://lpmpbanten.net.

Smart, C. (2005). Using Poems to Develop Productive Skills. Teaching English (An On-line journal). Diakses tanggal 27 Agustus 2010.

Undang-Undang Republik Indonesia No. 20/2003. Sistem Pendidikan Nasional. Diakses tanggal 26 Agustus 2017 dari http:// kelembagaan.ristekdikti.go.id/wpcontent/uploads/2016/08/UU_no_20_th_2003.pdf. 